\author{
ДАЛИБОР Соколовић* \\ Филолошки факултет Универзитета у Београду \\ Београд, Србија
}

\title{
МЕСТО СОРАБИСТИКЕ НА УНИВЕРЗИТЕТУ У БЕОГРАДУ У САВРЕМЕНИМ СОРАБИСТИЧКИМ ОКВИРИМА
}

\begin{abstract}
Рад представља хронолошко-аналитички приказ сорабистичких истраживања и подухвата у београдској универзитетској средини од почетака у међуратном периоду до данашњих дана, из перспективе општег развоја сорабистике у Европи. Интензивнији развој сорабистике у Београду бележи се у последњих двадесет година. Нарочити акцент је у раду стављен на сарадњу са осталим европским сорабистичким центрима, као и на могућности њеног побољшања.
\end{abstract}

Кључне речи: сорабистика, Универзитет у Београду, европски сорабистички центри

1. Српска академска средина показује повећано интересовање за Лужичке Србе већ током друге половине 19. века ${ }^{1}$. Српски научници, историчари и публицисти, нарочито са територија које су у том периоду још увек биле под аустроугарском управом, објављују путописе из Лужице и делова Немачке насељених словенским живљем. Касније се штампају прилози о лужичкосрпској књижевности и друштвеним приликама, у новосадским часописима Сеgмии, и Дании,а, али и у београдској Вили.

1.1. Међутим, истински почетак развоја београдске научне и универзитетске сорабистике бележимо тек у периоду између два светска рата. Јован Ердељановић, професор Универзитета у Београду и оснивач научне етнологије код Срба, издаје 1929. године у два наставка чланак у београдском Срйском књижевном ілласнику под називом Лужички Срби

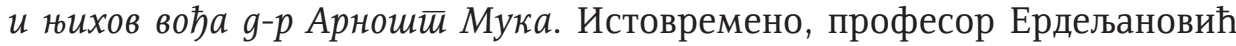
на нашем универзитету организује предавање посвећено овом лужич-

*dalibor.sokolovic@fil.bg.ac.rs

${ }^{1}$ Више информација о историјату сорабистичких истраживања на територији Србије може се наћи у: Sokolović, D. Sorabistika v Srbsku - historie, současnost a perspektivy rozvoje. v: Pražské sorabistické studie. Praha: Společnost přátel Lužice. 2013. s. 133-141. 
косрпском делатнику. Исте 1929. године, излази рад књижевног исто-

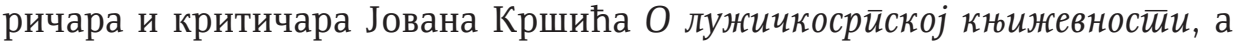
1936. историчара и публицисте Алексија Јелачића под насловом Траі̄oвима Словенсиива йо савременој Немачкој, оба у већ поменутом Срйском књижевном іласнику. Занимљиво је да су сви наведени аутори дипломци универзитета са простора некадашње Аустроугарске - Прага (J. Ердељановић, J. Кршић), Љубљане (А. Јелачић) - што је вероватно показатељ њихове истанчане осетљивости за проблеме са којима су у то време били сучељени Лужички Срби, у својој борби за одржање етничког и језичког идентитета, без праве политичке независности. Могуће из истих побуда, Словенац Леополд Ленард објављује 1930. године чланак у новосадском часопису Лейойис Матиие Срйске под насловом Послерайна књижев-

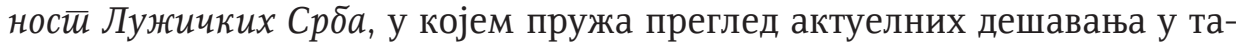
дашњој лужичкосрпској књижевности. Годину дана касније, у Београду излази књига његових књижевних есеја Срйстиво у йоезији лужичких Срба (публикација која је доживела и своје реиздање, у Краљеву 1995. године).

2. Успон и терор фашистичког режима онемогућили су озбиљније бављење сорабистиком у време пред и током 2. светског рата, на свим европским меридијанима. Након пада фашизма, Лужички Срби су само првих неколико година били у центру интересовања српске средине, услед поновног дефинисања граница у послератној Европи. У дугом периоду који следи, Срби у Југославији (за разлику од осталих конститутивних народа) као да су потпуно заборавили на своје северне имењаке. Два избора текстова из књижевности Лужичких Срба - Нароgне бајке Лужичких Срба објављен 1974. у Београду у редакцији Николе Јеремића и Књижевности Лужичких Срба издат 1984. године у Крагујевцу под уредништвом Радослава Братића, као и повремени преводи научних чланака, слика су, нажалост, минималног интересовања београдске и српске славистике за лужичкосрпску проблематику.

2.1. Изузетак од ове неочекиване равнодушности представљају радови и деловање др Наде Ђорђевић, београдске бохемисткиње и најзначајнијег представника српске сорабистике у 20. веку2. Нада Ђорђевић је, након студија на Карловом универзитету у Прагу, радила од 1950. до 1977. године у Институту за српскохрватски језик САНУ на изради Чещко-срйскої речника. Након пензионисања посветила се сорабистичким истраживањима, преводила је дела лужичкосрпске књижевности (Хандрија Зејлера, Јакуба Барта Ћишинског, Јозефа и Мјерћина Новака, Мине Виткојц) и вредно бележила све што се у Лужици дешавало:

${ }^{2}$ Sokolović, D. Nada Đorđević - významná kapitola dějin bělehradské bohemistiky a slavistiky. Славистика IX. 2005. s. 347-351. 
актуелна књижевно-научна и лингвистичка сорабистичка истраживања, најновију лингводидактичку литературу, културна дешавања, јубилеје важних личности из лужичкосрпске средине и сорабиста широм света. Њена сорабистичка библиографија налази се у електронској библиотеци $Р a c \bar{u} \kappa 0^{3}$ и броји више од 60 позиција. Радове је објављивала у преко 15 часописа у Србији (Книжевне новине, Зборник Маииие сритске за

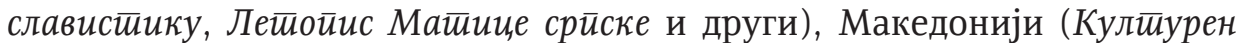
животи, Млаg бореи, Оїлеgало, Бесеgа) и Лужици (првенствено у часописима Lětopis и Rozhlad). За велики допринос успостављању и одржавању пријатељских односа између Срба на Балкану и Срба у Лужици 1998. од стране лужичкосрпске научне јавности награђена је престижном Наіраgом Домовине (Myto Domowiny).

2.2. Крајем прошлог века бележи се објављивање још једног рада значајног за историју српске научне сорабистике - у Новом Саду 1995. године излази студија др Мића Цвијетића под називом Лужички Срби и Јуі̄ословени og 1840. go 1918. їоguне. Основу публикације чини докторска дисертација одбрањена на Филолошком факултету у Београду, израђена за време ауторовог боравка у Лајпцигу као лектора српскохрватског језика. Дело је посвећено књижевним везама између Лужичких Срба и југословенских народа у књижевној периодици у периоду 1840-1918. Мићо Цвијетић 1997. године објављује избор путописа Коg Лужичких Срба, који „актуализује” издањем из 2009. године У лейој gомовини Лужичких Срба. Ова књига доноси путописне утиске аутора са излагањем историјских чињеница о Лужичким Србима, њиховој традицији и идентитету, његово виђење политичких прилика у Лужици и портрете најистакнутијих представника лужичкосрпског књижевног, научног и културног живота. Девете деценије минулог столећа светло дана угледале су и две публикације које Лужичке Србе сагледавају кроз призму генеалошке сродности са њиховим имењацима на словенском Југу и у контексту теорија о пореклу Срба, изузетно популарних у том периоду развоја српског друштва. Реч је о књигама Лужички Срби Лазара Шебека, издатој 1997. у Београду, и Северни Срби. (Не)заборављени нароg, ауторства Саве Вујића и Богдана Басарића из 1998. године. На почетку миленијума појављују се радови домаћих србиста посвећени сорабистичкој тематици. Такав је рад $O$ неким йаралелама између лужичкосрйскоі и сх језика Богдана Дабића у часопису Наш језик (број 3-4 за године 2002-2003), у ком аутор разматра језичке односе измећу два словенска народа са истим именом на нивоу стандардног језика. Читав број часописа Књижевна реч из 2001. године посвећен је Лужичким Србима.

\footnotetext{
${ }^{3}$ http://www.rastko.rs/rastko-lu/ndjordjevic-luzicani/bibliografija.html
} 
3. И премда је током последње две деценије 20. века уочљива повећана фреквенција сорабистичких истраживања у београдској академској средини, први успешан покушај подизања сорабистике на виши, универзитетски ниво треба приписати професору Филолошког факултета у Београду, академику Предрагу Пиперу. Поред тога што су основне информације о Лужичким Србима укључене у курикулуме из предмета Увод у славистику за студенте прве године славистичких профила, Предраг Пипер је 2002. године, у сарадњи са водећим особљем пројекта електронских библиотека српске културе Расйко, уредио и објавио библиотеку Расйко-Лужиц, $a^{4}$. Она садржи око 200 радова више од 80 аутора, на неколико језика, и представља највећу дигиталну сорабистичку библиотеку у свету. Њен главни сегмент је Увоg у сорабистику који у облику хрестоматије доноси текстове из којих читаоци могу стећи основна знања из области сорабистике и први је такве врсте на овдашњим просторима. Расйко-Лужища такође доноси изабрану библиографију сорабистичких радова на српском (српскохрватском) језику, већ поменуту библиографију радова Наде Ђорђевић на пољу сорабистике, електронска издања Нароgних бајки Лужичких Срба из 1974. године и Кюижевносичи Лужичких Срба из 1984, као и две збирке: Поезија Лужичких Срба и

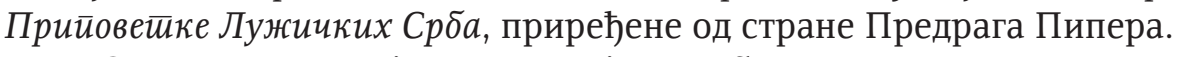

3.1. Нови стадијум у развоју сорабистике у Београду почиње школске године 2002/2003, када на Универзитету у Лајпцигу на једногодишњим сорабистичким студијама као стипендиста Фондације за лужичкосрпски народ (Załožba za serbski lud) борави Далибор Соколовић, тадашњи асистент на групи за словачки језик и књижевност. По његовом повратку из Немачке, сарадња са П. Пипером и М. Цвијетићем резултирала је одржавањем Дана лужичкосрйских језика, књижевносиии и кулишуре 2004. године, у периоду 8-12. марта, на Катедри за славистику Филолошког факултета у Београду, уз гостовање истакнутог прашког сорабисте Петра Калете. Повод је била 150. годишњица рођења Арношта Муке, великог научника и вође Лужичких Срба.

3.2. Догађај је започео отварањем изложбе Лужичкосрйска литерайура у читаоници библиотеке Катедре за славистику, скромне по свом обиму, али уз достојну репрезентацију сорабистичких издања. Уводно предавање на тему Науиник и свестирани кулйурни раяник Арношй Мука одржао је Мићо Цвијетић. Говорио је о Мукином научном и културном деловању, као и околностима у којима је живео и радио. Цвијетић је том приликом указао на Мукину улогу као вође свог народа, његов рад у вези са проучавањима језичких и књижевних споменика, његово пионирско деловање на пољу статистике, издавачки и уређивачки рад за опште доб-

${ }^{4}$ http://www.rastko.rs/rastko-lu/ 
ро науке и ширење знања о Лужичким Србима. Српска краљевска академија наука и уметности га је 1903. изабрала за почасног члана, а две године касније постао је почасни члан Матице српске у Новом Саду. М. Цвијетић је даље истакао да се у међуратном периоду на Универзитету у Београду одржало више предавања о Лужичким Србима, једно од њих је поменуто предавање професора Јована Ердељановића, одржано приликом 75. рођендана и 50 година бављења науком Арношта Муке. Мићо Цвијетић је у свом другом предавању размотрио опште лужичкосрпско-српске књижевне и културне односе, именујући при том најважније представнике међусобног деловања обеју страна. Професор Предраг Пипер, тадашњи управник Катедре за славистику, посветио се у својим предавањима лингвистичким питањима, концентришући се на компаративистичку проблематику. У предавању под називом Сорабистикка у ср-

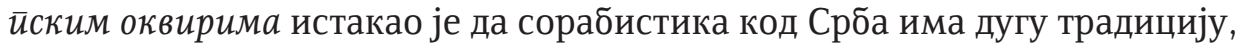
много дужу него што се мислило. Сорабистичким темама бавио се велики број српских научника, као и много сарадника српских часописа. У вези с тим, професор Пипер понудио је преглед главних научних питања, којима су се посветили аутори у часописима и књигама, укључујући и докторске дисертације које су већ одбрањене или на којима се још увек радило. У свом другом предавању, представио је најважније типолошке карактеристике проистекле из структурних и функционално-семантичких разлика између граматичких система горњолужичкоспрског и српског језика. Гост из Прага, Петр Калета са Масариковог института Чешке академије наука, говорио је у своја два предавања о чешко-лужичкоспрким контактима од почетака до краја 19. века и о историји, улози и задацима чешке сорабистике. Том приликом је нарочито истакао улогу Адолфа Черног, великог пријатеља Лужичких Срба и особу која је успостављала односе и са другим словенским народима. Далибор Соколовић

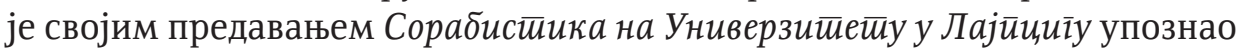
београдску славистичку публику са историјом сорабистичких студија на Институту за сорабистику у Лајпцигу, тренутним стањем, плановима, програмима и перспективама. Нарочити акцент стављен је на потребу и могућности даљег развоја заједничке сарадње између српске и немачке сорабистичке средине. У још једном предавању, О језичкој йолийиนи у Лужищи, млади слависта Соколовић представио је лингвистичке и екстралингвистичке околности које утичу на језичку ситуацију и политику код Лужичких Срба. Током Дана лужичкосрйских језика, књижевносиии u кулйуре представљен је и лужичкосрпски видео-пројекат Hrodźišćo, a уприличена је и презентација електронске библиотеке Расйко-Лужииа. Све се завршило књижевним матинеом, читањем изабране лужичкосрпске поезије у извођењу студената београдске славистике. 
3.3. Након овог дешавања, уследило је петнаест сорабистичких радова Далибора Соколовића, објављених у Србији (Слависииика, 3бор-

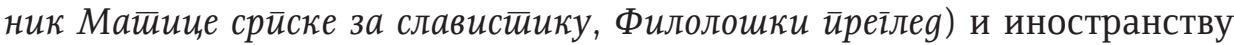
(Lětopis, Rozhlad, Pro Lusatia, Zeszyty Łużckie), пре свега из области теорије језичких мањина, језичког планирања и политике, као и историје сорабистике. Својим приказима Д. Соколовић је такође информисао српску славистичку јавност о најновијим позицијама у оквиру сорабистичке литературе, као и о актуелним сорабистичким дешавањима широм Европе. Обједињавање његових сорабистичких интересовања представља докторска дисертација, у којој се упоређује језичка ситуација лужичкосрпских језика и словачког језика у Војводини из перспективе социолингвистике. Докторска теза, под насловом $O$ манинским словенским језиицма из иерсииектииве еколоїије језика на ирримеру Лужичких Срба u војвођанских Словака одбрањена је почетком 2015. године на Филолошком факултету Универзитету у Београду.

3.4. Гостопримство Фондације за лужичкосрпски народ у протеклом периоду имали су прилике да искористе и следећи студенти Универзитета у Београду: Даница Пипер (школска година 2003/4), Предраг Обућина (2006/7), Марко Стојиљковић (2009/10) и Александар Јовановић $(2016 / 17)$. Не треба изгубити из вида ни боравке српских учесника на Феријалном курсу који се сваке друге године организује у Будишину (једном у Котбус) од стране Лужичкосрпског института. Предраг Обућина, београдски полониста, организовао је током 2007. године интензивни курс горњолужичкосрпског језика у трајању од три недеље. На курсу су учествовали студенти Филолошког и Филозофског факултета у Београду, асистенти Катедре за славистику и сарадници Института за српски језик.

3.6. Следећи сорабистички подухват на Катедри за славистику у Београду одиграо се у новембру 2016. године. У оквиру манифестације под већ поменутим називом Дани лужичкосрйских језика, књижевносиии u кулйуре заинтересовани студенти имали су прилику да се ближе упознају са историјом и актуелном ситуацијом најмањег словенског народа. Програм је започео 7. новембра промоцијом двојезичне српско-лужичкосрпске збирке поезије Бенедикта Дирлиха Ивањске ноћu/Janske nocy, коју је на српски препевао Мићо Цвијетић. Током исте седмице одржан је и кратак течај горњолужичкосрпског језика за студенте и наставнике Филолошког факултета, на којем су полазници могли да се упознају са основама граматичке и комуникацијске структуре овог језика. Главни сегмент другог издања београдских сорабистичких сусрета одиграо се у данима 14-16. новембра, када су сорабисти из више европских земаља одржали предавања са различитом тематиком. Петр Калета је београдским студентима представио кратак преглед историје Лужичких 
Срба предавањем под називом Лужички Срби. Увоg у њихову истиорију u кулйуру, као и опус Адолфа Черног - Аgолф Черни као сорабистиа и ироуиавалаи, малих словенских ейничких зајеgница. Мићо Цвијетић се осврнуо на српско-лужичкосрпске односе предавањем Преїлеg срйсколужиикосрйских књижевних и кулйурних оуноса, Јан Красни је анализирао лужичкосрпску елиту и мултикултурализам Лужице у излагању

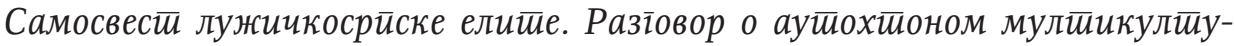
рализму Лужица, док је Далибор Соколовић окупљеној публици прибли-

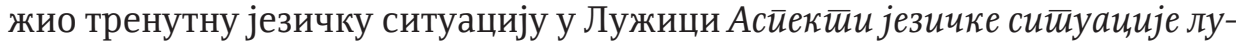
жичкосрйске зајеgнище. Последњег дана сусрета публици су се обратили Предраг Обућина контрастивном анализом категорије двојине и множине у српском, пољском и лужичкосрпском језику - Лужичкосрйски

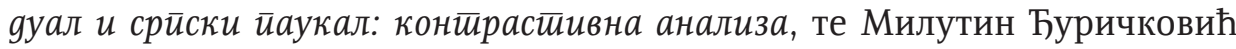
информацијама о лужичкосрпској књижевности за децу - Лужичкосрйска књижевности за gецу и млаgе. Ово сорабистичко дешавање пропраћено је добрим интересовањем како студената, тако и наставног особља Катедре за славистику, што пружа наду да ће се започета традиција у будућности наставити.

4. Представљена сорабистичка истраживања и најзначајнија дешавања из досадашњег дела 21. века дају нам за право да закључимо да се сорабистика у Београду одржава на нивоу достигнутом у претходном периоду и даље развија, у складу са могућностима. На овом месту треба истаћи да се сорабистика негује у само неколико европских научних центара и институција. На територији Русије је то, на пример, Институт за словенске студије Руске академије наука или Филолошки факултет Московског државног универзитета; у Украјини Катедра за словенску филологију Лавовског националног универзитета; у Пољској Институт за словенску филологију на Универзитету у Варшави и Пољско-лужичкосрпско удружење (Stowarzyszenie Polsko-Serbołużyckie Pro Lusatia) у Ополу ${ }^{5}$. На Филозофском факултету Карловог универзитета у Прагу сорабистика се изучавала још од 1901. године, а 1933. била је основана и самостална катедра сорабистике, чији је први професор био познати чешки слависта Јозеф Патаб. Ова катедра данас, нажалост, не постоји, тако да је сорабистичке активности на себе углавном преузело Друштво пријатеља Лужице (Společnost prátel Lužice) ${ }^{7}$.

\footnotetext{
${ }^{5}$ http://prolusatia.pl/

${ }^{6}$ Аутор досад јединог лексикографског дела, издатог 1921. године, које повезује српски и лужичкосрпски језик - Kapesní slovník lužicko-česko-jihoslovanský a česko-lužický, Praha: Českolužický spolek „Adolf Černý”.

${ }^{7} \mathrm{http}: / /$ www.luzice.cz/
} 
4.1. У данашње време, једина земља у свету у којој су се одржале сорабистичке универзитетске студије је Немачка - на Институту за сорабистику Универзитета у Лајпцигу ${ }^{8}$, као и у ограниченом обиму на Универзитету у Потсдаму. Лужички Србин Јан Петр Јордан је на Универзитету у Лајпцигу држао предавања о лужичкосрпском језику више од двадесет година пре званичне иницијације (у периоду 1843-1848) славистичких истраживања од стране Августа Лескина 1870. На овом универзитету школовали су се водећи представници евангелистичке лужичкосрпске интелигенције, а у периоду социјализма на њему су радили најистакнутији немачки сорабисти. Данас се у Лајпцигу образују особе које посао налазе у школама и другим државним институцијама у Горњој и Доњој Лужици. Њихова улога у процесу одржавања и ревитализације ових угрожених језика (нпр. у пројекту Witaj) је велика. Међутим, суочена са све мањим бројем кандидата, рестриктивном политиком према друштвеним наукама - чини се, свеприсутном у савременој Европи - управа Института за сорабистику одлучила је да свој програм обогати понудом проучавања других европских мањинских језика који се налазе у блиској позицији - ирским ${ }^{9}$. Такође, све је више пројеката реализованих у сарадњи са сличним словенским центрима, нпр. пољским универзитетима у Шчећину, Гдањску (кашупски језик).

4.2. Одржавање сарадње на досадашњем нивоу и њено интензивирање са горе поменутим европским сорабистичким центрима - основни су задаци београдских сорабиста у будућности. Исто тако, позитивне ефекте донело би и удруживање снага сорабистички усмерених културних и просветних радника у Србији. Резултат би свакако био већи број пројеката и подухвата на пољу популаризације науке о Лужичким Сpбима, о којима се и даље веома мало зна, чак и у широј српској научној јавности. На универзитетској разини, основни циљеви у предстојећем периоду биће развој сорабистичке литературе на српском језику за заинтересоване студенте, повећање броја превода са лужичкосрпских језика, а у оптималном развоју ситуације и успостављање посебног предмета на Катедри за славистику на којем би студенти Филолошког факултета имали прилику да стекну основна сорабистичка знања.

\footnotetext{
${ }^{8}$ Соколовић, Д. Сорабистика на Универзитету у Лајпцигу. Зборник Матице српске за славистику 67. 2005. с. 157-165.

${ }^{9}$ Wornar, E. Nowe perspektiwy za Lipšćansku sorabistiku. Zeszyty Łużyckie 50. 2016. s. $67-77$.
} 
Dalibor Sokolović

\section{THE PLACE OF SORABISTIC STUDIES AT THE UNIVESITY OF BELGRADE IN CONTEMPORARY SORABISTIC FRAMEWORKS}

\section{Summary}

The paper presents a chronological and analytical presentation of Sorabistic research and endeavors at the University of Belgrade from its beginning in the interwar period to the present day, from the perspective of the overall development of Sorabistic studies in Europe. The more intense development of Sorabistic studies in Belgrade has been recorded in the last twenty years. Cooperation with other European centers for Sorabistic studies is emphasized, as well as the possibilities of its improvement.

Key words: Sorabistics, University of Belgrade, European centers for Sorabistic studies 